Quebec Cooperative Study

of Friedreich's Ataxia

\title{
Active Pyruvate Dehydrogenase In Platelets From Friedreich's Ataxia Patients
}

\author{
A. FILLA, R.F. BUTTERWORTH, A. BARBEAU
}

SUMMARY: Pyruvate dehydrogenase $(P D H)$ activity was measured in platelets from 10 patients with Friedreich's ataxia, and 10 age-matched healthy control subjects. Both total PDH and active PDH activity were measured. There were no significant differences between the two groups.

RESUME: Nous avons mesurél'activité de la pyruvate déshydrogenase $(\mathrm{PDH})$ dans les plaquettes de 10 patients souffrant d'ataxie de Friedreich et de 10 témoins normaux apparillés pour l'âge. L'activité totale ainsi que la portion active du PDH furent mesurées. Aucune différence significative entre les deux groupes ne fut trouvée.
From the Department of Neurobiology. Clinical Research Institute of Montreal.

Reprint requests for the complete supplement on Friedreich's Ataxia (phase three) to: Dr. André Barbeau, Clinical Research Institute of Montreal, 110 Pine Avenue West, Montreal, Quebec, Canada, H2W IR7.

\section{INTRODUCTION}

Pyruvate dehydrogenase (PDH) is a multienzyme system that can be purified and separated into at least three separate components (Reed, 1974). The three enzymes comprising the PDH are: pyruvate decarboxylase $\left(E_{1}\right)$ (E.C.4.1.1.1.), a thiamine pyrophosphate (TPP) dependent enzyme, dihydrolipoyl transacetylase $\left(E_{2}\right)$ (E.C. 2.3.12) and dihydrolipoyl dehydrogenase $\left(\mathrm{E}_{3}\right)$ (E.C.1.6.4.3) also called lipoamide dehydrogenase (LAD) employing flavin-adenine-dinucleotide (FAD) as co-factor and under the control of the nicotinamide-adeninedinucleotide (NAD-NADH) reaction. They exist in a molecular ratio of 12:1:6 (Linn et al. 1972). $\mathrm{E}_{1}$ component in PDH complex appears to be present in excess, whereas either $E_{2}$ or $E_{3}$ are the apparent limiting components of the PDH system (Farrell et al. 1974). The PDH complex in vivo exists in an active and inactive form (Wieland et al. 1971). The conversion from the active to the inactive form is catalyzed by the kinase, pyruvate decarboxylase: ATP transphosphorylase, with the conversion from the inactive to the active form being catalyzed by a magnesium dependent phosphatase: pyruvate decarboxylase phosphate phosphatase.

PDH is situated at the crossroads of several metabolic routes: the generation of ATP through acetyl-coenzyme A (acetyl-CoA) and the Krebs cycle; carboxylation to form oxaloacetate and the starting point of gluconeogenesis; through acetyl-CoA the biosynthesis of fatty acids, prostaglandins, steroidal hormones and acetylcholine. Finally, pyruvate can supply the carbon skeleton for de novo synthesis of non essential amino acids. Many hormonal, ionic and metabolic factors regulate $\mathrm{PDH}$ complex at various sites.

Severe impairment of this enzyme is joined with serious clinical features and death (Farrell et al. 1974) whereas patients with partial deficiencies of PDH present cerebellar ataxia as the most prominent and sometimes the only neurologic abnormality (Blass et al. 1971; Oka et al. 1976; Falk et al. 1976; Wick et al. 1977; Blass et al. 1976). Reynolds et al. (1976) demonstrated that the reduction of the activity of PDH to less than 30 percent of normal impaired pyruvate oxidation in the brain and that deficiencies too mild to impair oxidation in several other parts of the brain could do so in the anterior cerebellar vermis.

Decreased PDH activity (40 percent of normal) due to impairment of $E_{3}$ (Kark et al. 1977) has been described by Blass et al. (1976) in various tissues from patients affected by Friedreich's ataxia.

Our previous study (Filla et al. 1978) on platelets from patients affected by Friedreich's ataxia showed only a slight and not significant decrease of PDH (16\%) and $E_{3}$ (15\%). These results suggested that $\mathrm{PDH}$ impairment was not the primary genetic deficiency in that disease, but only a regulatory defect. In order to further investigate the nature of this impairment we studied the activation of PDH in platelets.

\section{SUBJECTS, MATERIALS AND METHODS}

\section{Subjects}

PDH activity in platelets was estimated in 10 patients with typical Friedreich's ataxia (Group Ia, according to the clinical criteria of Geoffroy 
TABLE I

\begin{tabular}{lcccc}
\hline & N & PDH Active & PDH Total & \% Active \\
\hline Patients & 10 & $43.46 \pm 7.79$ & $200.57 \pm 19.86$ & 21.67 \\
Controls & 10 & $50.21 \pm 7.93$ & $220.93 \pm 27.27$ & 22.73 \\
\hline
\end{tabular}

$\mathrm{PDH}$ activity, mean $\pm \mathrm{S}$.E., is expressed in $\mathrm{pmol} / \mathrm{min} / \mathrm{mg}$ protein.

et al. 1976) from different families and 10 age-matched healthy controls. In each experiment samples from one patient and the control were run together.

\section{Materials}

Sodium $\left(1-\mathrm{C}^{14}\right)$ pyruvate $(4.8 \mathrm{Ci} / \mathrm{mol})$ was purchased from New England Nuclear Corp. Glycerol, nicotinamide, NAD (grade III yeast), thiamine pyrophosphate chloride, hyamine hydroxide and bovine serum albumine were obtained from Sigma Chemical Corp. Coenzyme A was bought from P-L Biochemicals Inc. Toluene "scintanalyzed grade", methanol "spectranalyzed" were from Fisher Scientific Co. and liquifluor from New England Nuclear. All other reagents were of analytical grade.

\section{Methods}

PDH assay was performed using modifications of the method described by Blass et al. (1977). Platelets were isolated as described previously (Filla et al. 1978). To the final pellet was added $1.2 \mathrm{ml}$ of glycerol buffer mixture ( 2 parts of glycerol and 3 parts of $0.0324 \mathrm{M}$ potassium phosphate buffer, $\mathrm{pH} 7.4$, containing $30 \mathrm{mM}$ nicotinamide, $7 \mathrm{mM} \mathrm{Na} \mathrm{SO}_{3}, 6 \mathrm{mM}$ DLdithriothreitol). Then the cells were disrupted by homogenization in an ice bath. Protein detection was done according to the Lowry's technique (1951). In $15 \times 50 \mathrm{~mm}$ plastic tubes, in ice, were mixed $200 \mu$ l of potassium phosphate buffer ( $\mathrm{pH}$ 7.4) for active $\mathrm{PDH}\left(\mathrm{PDH}_{\mathrm{a}}\right)$ detection, $200 \mu \mathrm{l}$ of homogenate and $10 \mu \mathrm{l}$ of $7.5 \mathrm{mM}$ phosphate buffer for total PDH $\left(\mathrm{PDH}_{t}\right)$ detection. The assays were done in triplicate. Blanks were obtained by adding $0.1 \mathrm{ml}$ of ion $\mathrm{H}_{2} \mathrm{SO}_{4}$ to the reaction mixture. The samples were incubated for 60 minutes at $30^{\circ} \mathrm{C}$, before adding $10 \mu \mathrm{l}$ of a solution containing CoA, NAD, TPP $(2 \mathrm{mM}$ each) in $0.0324 \mathrm{M}$ potassium. Phos-

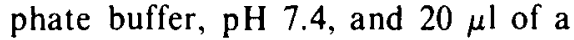
solution of $1.8 \times 10^{5} \mathrm{cpm}$ sodium (1$\left.{ }^{14} \mathrm{C}\right)$ pyruvate in the same buffer. Then the samples were incubated again for 30 min at $37^{\circ} \mathrm{C}$ and $\mathrm{CO}_{2}$ was collected after acidification of the mixture and counted as described previously (Filla et al. 1978).

\section{RESULTS AND DISCUSSION}

The values of $\mathrm{PDH}_{\mathrm{a}}$ and $\mathrm{PDH}_{\mathrm{t}}$ in platelets are shown in Table I. Twenty percent of PDH was usually in the active form. Diet did not appear to alter this ratio thus confirming previous results (Blass et al. 1979). No significant difference was found between patients and controls with Student's paired $T$ test, although the ataxic patients showed slightly lower values of $\mathrm{PDH}_{\mathrm{a}}$ and $\mathrm{PDH}_{\mathrm{t}}$ (respectively $10 \%$ and $15 \%$ less than controls).

The present results confirm our previous report (Filla et al., 1978) that PDH activity in platelets from patients affected with Friedreich's ataxia is normal. The patients selected for this study were different from the initial group and responded to all the criteria of typical Friedreich's ataxia listed by Geoffroy et al. (1976). We now add that the percentage of activated PDH from the total PDH measured is not different from normal in these patients. This overall situation confirms the results of Stumpf and Parks (1978), but not those of Kark et al. (1980). However, we have not measured the Michaelis-Menten constants for this enzyme. The non significant decrease in PDH activity is probably the result of a regulatory deficit elsewhere in the system.

\section{ACKNOWLEDGEMENTS}

This study was supported by a grant from l'Association Canadienne de l'Ataxie de Friedreich. We thank Miss M. Charbonneau for technical assistance. and Miss Bedard. RN for help with the patients.

\section{REFERENCES}

BLASS, J.P., KARK, R.A.P. and ENGEL, W.K. (1971): Clinical studies of a patient with pyruvate decarboxylase deficiency. Arch. Neurol. 25: 449-460.

BLASS, J.P., KARK, R.A.P., and MENON, N.K. (1976): Low activities of the pyruvate and oxoglutarate dehydrogenase complexes in five patients with Friedreich's ataxia. N. Engl. J. Med. 295: 62-67.

BLASS, J.P., CEDERBAUM, S.D., and KARK, R.A.P. (1977): Rapid diagnosis of pyruvate and ketoglutarate dehydrogenase deficiencies in platelet-enriched preparations from blood. Clin. Chim. Acta 75: 21-30.

FALK, R.E., CEDERBAUM, S.D., BLASS, J.P., GIBSON, G.E., KARK, R.A.P., and CARREL, R.E. (1976): Ketonic diet in the management of pyruvate dehydrogenase deficiency. Pediatrics 58: 713-721.

FARRELL, D.F., CLARK, A.F., SCOTT, C.R., WENNBERG, R.P. (1974): Absence of pyruvate decarboxylase activity in man: a cause of congenital lactic acidosis. Science 187: 1082-1084

FILLA, A., BUTTERWORTH, R.F., GEOFFROY, G., LEMIEUX, B., and BARBEAU, A. (1978): Serum and platelet lipoamide dehydrogenase in Friedreich's ataxia. Can. J. Neurol. Sci. 5: 111-114.

GEOFFROY, G., BARBEAU, A., BRETON, G., LEMIEUX, B., AUBE, M., LEGER, C., BOUCHARD, J.P. (1976): Clinical description and roentgenologic evaluation of patients with Friedreich's ataxia. Can. J. Neurol. Sci. 5: 279-286.

LINN, T.C., PELlEY, J.W., PETTIT, F.H., HUCHO, F., RANDALL, D.D., and REED, L.J. (1972): $\alpha$-Keto acid dehydrogenase complex XV. Purification and properties of the component enzymes of the pyruvate dehydrogenase complexes from bovine kidney and heart. Arch. Biochem. Biophys. 148: 327-342.

LOWRY, O.H., ROSEBROUGH, N.J., FARR, A.L. and RANDALL, R.J. (1951): Protein measurement with the folin phenol reagent. J. Biol. Chem. 93: 265-275.

KARK, R.A.P., RODRIGUEZ-BUDELLI, M. (1977): Lipoamide dehydrogenase deficiency in a patient with Friedreich's ataxia. Clin. Res. 25: 131A.

KARK, R.A.P., RODRIGUEZ-BUDELLI, M., PERMAN, S., GULLEY, W.F. and TOROK, K. (1980): Pre-clinical diagnosis and carrier detection in ataxia associated with abnormalities of lipoamide dehydrogenase. Neurology 30: 502-508.

OKA, Y., MATJUDA, I., ARASHIMA, S., ANAKURA, M., MITJUYAMA, T. and NAGAMATSU, I. (1976): Citrate treat ment 
in a patient with pyruvate decarboxylase deficiency. Tohoku J. Exp. Med. 118: 131135.

REED, L.J. (1974): Multienzyme complexes. Accounts of Chem. Res. 7: 40-46.

REYNOLDS, J.F. and BLASS, J.P. (1976): A possible mechanism for selective cerebellar damage in partial dehydrogenase deficiency. Neurology 26: 625-628.
STUMPF, D.A. and PARKS, J.K. (1978): Friedreich's ataxia: I. Normal pyruvate dehydrogenase complex activity in platelets. Am. Neurol. 4: 366-368.

WICK, H., SCHWEIZER, K., BAUMGARTNER, R. (1977): Thiamine dependency in a patient with congenital lacticacidoemia due to pyruvate dehydrogenase deficiency. Agents and Actions 7: 405-410.
WIELAND, D., SIESS, E., SCHULZEWETHMAR, F.H., V. FUNKE, H.G. and WINTON B. (1971): Active and inactive forms of pyruvate dehydrogenase in rat heart and kidney: effect of diabetes, fasting and refeeding on pyruvate dehydrogenase interconversion. Arch. Biochem. Biophys. 143: 593-601. 